\title{
Article \\ The Impact of Narrative Feedback, E-Learning Modules and Realistic Video and the Reduction of Misconception
}

\author{
Abdul Halim ${ }^{1, *}$, Elmi Mahzum ${ }^{1}$, Muhammad Yacob $^{2}$, Irwandi Irwandi ${ }^{3,4} \oplus$ and Lilia Halim ${ }^{5}$ \\ 1 Department of Physic Education, Teacher Training and Education Faculty, Universitas Syiah Kuala, \\ Aceh 23111, Indonesia; helmiarsal@unsyiah.ac.id \\ 2 Department of Physic Education, Teacher Training and Education Faculty, Universitas Samudra, Langsa, \\ Aceh 24415, Indonesia; myakob@unsam.ac.id \\ 3 Department of Physics, Faculty of Science and Mathematics, Universitas Syiah Kuala, Aceh 23111, Indonesia; \\ irwandi@unsyiah.ac.id \\ 4 STEM Study Center, Universitas Syiah Kuala, Aceh 23111, Indonesia \\ 5 Faculty of Education, Universiti Kebangsaan Malaysia, Bangi 43600, Malaysia; lilia@ukm.edu.my \\ * Correspondence: abdul.halim@unsyiah.ac.id
}

\section{check for}

updates

Citation: Halim, A.; Mahzum, E.; Yacob, M.; Irwandi, I.; Halim, L. The Impact of Narrative Feedback, E-Learning Modules and Realistic Video and the Reduction of Misconception. Educ. Sci. 2021, 11, 158. https://doi.org/10.3390/ educsci11040158

Academic Editor: Jon Mason,

Christian M. Stracke, Daniel Burgos, Cleo Sgouropoulou and Jin Gon Shon

Received: 22 February 2021

Accepted: 22 March 2021

Published: 31 March 2021

Publisher's Note: MDPI stays neutral with regard to jurisdictional claims in published maps and institutional affiliations.

Copyright: (c) 2021 by the authors. Licensee MDPI, Basel, Switzerland. This article is an open access article distributed under the terms and conditions of the Creative Commons Attribution (CC BY) license (https:/ / creativecommons.org/licenses/by/ $4.0 /)$.

\begin{abstract}
Physics learning in universities utilized the Moodle-based e-learning media as an online learning platform. However, the effectiveness of remediating misconception using online media has not been widely researched. Therefore, this study was set to determine the level of misconception percentage reduction through the use of narrative feedback, the e-learning modules, and realistic video. The study was a quantitative approach with a quasi-experimental method involving 281 students who were taking basic physics courses in the Department of Physics, Chemistry, and Biology Education. The data collection used a three-tier diagnostic test based on e-learning at the beginning of the activity and after the treatment (posttest). The results of the data analysis with descriptive statistics show that the most significant treatment in reducing misconception percentage on the topic of free-fall motion was in the following order: narrative feedback, e-learning modules and realistic video. The misconception percentage reduction in the sub-concept of accelerated freefall was effective for all types of the treatments.
\end{abstract}

Keywords: distance learning; remediation; diagnostic test; free-fall motion

\section{Introduction}

The term "reducing misconception" has been used with various kinds of words by conceptual research experts, including the terms "to combat and antidote to misconception" used by Styer [1], "to overcome misconception" [2-5], "to prevent and challenge misconception" used by Marshall [6], "to eradicate misconception" in Podolner's study [7], "to remediate misconception" [8,9] and "to reduce misconception" [10]. All of these terms, even though they have different meanings, have the same purpose, namely, to eliminate misconception in students. So far, the reduction of misconception in students has been implemented conventionally (face to face) by utilizing independent modules [11], using analogous learning approaches [12-16], cognitive conflict methods [17], through peer group interactions [18], and feedback $[19,20]$.

Hattie [21] has stated that narrative feedback is a conceptualization of information conveyed by certain agents (teachers, parents, books, experiences, etc.) regarding performance results. Narrative feedback has shown advanced power to improve students' learning outcomes. The results of a meta-analysis conducted by Hattie on 30 million students around the world showed that narrative feedback had a high impact on learning by conveying information about assignments and completing tasks more effectively than praise, reward, and punishment, which have a very low impact [22,23]. The narrative feedback can be used on formative examinations to increase students' scientific argumentation skills [24,25], to 
understand teacher-students perceptions and relationships [26], to design teaching strategies in higher education, [27], and to increase students' learning outcomes and memory [28]. These studies showed that the impact of narrative feedback on learning outcomes is higher than online videos [29-31]. Based on the analysis of the previous studies, there has not been any effect of narrative feedback on reducing misconception, but narrative feedback has had a significant effect on learning outcomes. This finding implied that narrative feedback also has an impact on understanding concepts or reducing misconception. The study of reducing misconception using narrative feedback based on Moodle's e-learning is one of the novelties of this study, and the results are the most important and newest contribution to the field of misconception remediation research.

The advancement of internet technology has been widely used as online-based learning media in the form of learning modules and online computer-assisted tests. E-learning technology, as one of the online medias, is widely utilized for the implementation of the learning process [32,33], as well as used as a learning evaluation instrument [34-36]. One of the well-known and widely applied e-learning based learning tools is the e-learning module. An overview of several resources and learning activities that are integrated into Moodlebased e-learning is known as the e-learning module [37]. E-learning modules have been used to see the impact on students' knowledge and skills [38,39]; students' involvement and attendance in the learning process [40]; students' learning outcomes, understanding and motivation [41,42]; and students' cooperative behavior and attitudes [43]. Besides that, the e-learning module has also been used to develop entrepreneurial thinking [44], higher-order thinking skills, and for the reduction of misconception [45-49].

Realistic video is a common name for several types of video that are often utilized in teaching and learning the free-fall motion concept, including video trackers, video hammer vs feather in the Moon, and video Galileo's Famous Gravity Experiment. Realistic video is an interactive learning medium and has the convenience of analyzing the graphics of moving objects [50], free-falling objects [51,52], and determining moments of inertia [53]. There are several advantages of realistic video compared to online video, including being able to improve critical thinking skills [51,54], reduce the percentage of misconception [55-59], and increase students' graphic literacy [60]. Realistic video in MP4 format can be integrated into the e-learning module, making it easier for students to understand the phenomenon of free-fall motion. Students who misunderstand the concept of free-fall motion, which can be found in the three-tier diagnostic test at the beginning of the lesson, can find answers through realistic video. Efforts to reduce misconception through realistic videos that are integrated into the e-learning module during the Covid-19 pandemic is the second novelty of this study. Based on the results of the analysis of the previous research, it is necessary to further detect the level of effectiveness of narrative feedback, e-learning modules and realistic video, viewed from the misconception percentage reduction of free-fall motion. Therefore, the aim of this study is to determine the effectiveness of misconception remediation using narrative feedback, e-learning modules and realistic video as seen by misconception reduction or posttest results' score increase on the free-fall motion concept.

The research questions in this study are as follows. Q1: What percentage is the pretest contribution to the posttest score in each treatment (narrative feedback, e-learning modules, and realistic video)? Q2: How does the treatment (narrative feedback, realistic video, and e-learning module) affect the increase in posttest scores? Q3: How does the treatment (narrative feedback, realistic video, and e-learning modules) affect the misconception percentage reduction? Q4: How is the relationship between the free-fall motion sub-concept and the type of treatment viewed from the point of view of misconception reduction?

\section{Materials and Methods}

\subsection{Research Design and Sample}

This is quantitative approach research with a quasi-experimental method and a threegroup pretest and posttest design. The research sample was all first-year students in the Department of Physics, Chemistry, and Biology, Teacher Training and Education Faculty, 
Syiah Kuala University, who were currently taking the basic physics course. The groups are divided as follows: Group Phys. 1-Phys. 3 from the Department of Physics Education comprised 94 students, Phys. 4-Phys. 5 from the Department of Biology Education major consisted of 77 students, and Phys. 6-Phys. 9 from the Department of Chemistry Education involved 110 students. The total of the sample was 281 respondents, as shown in Table 1. Even though the students came from different science majors, they were still in science disciplines and their background knowledge is the same, namely, that gained from the completion of senior high school. Besides that, the first-year students acquired basic knowledge which was not affected by the subjects in their majors in higher education.

Table 1. Research design and sample.

\begin{tabular}{ccccc}
\hline Groups & Amount & Pretest & Treatment & Posttest \\
\hline Phys.1 & 38 & $\mathrm{Q} 1$ & X1 (video) & Q2 \\
Phys.2 & 32 & $\mathrm{Q} 1$ & X1 (video) & Q2 \\
Phys.3 & 24 & $\mathrm{Q} 1$ & X1 (video) & Q2 \\
Phys.4 & 29 & $\mathrm{Q} 1$ & X2 (feedback) & Q2 \\
Phys.5 & 25 & $\mathrm{Q} 1$ & X2 (feedback) & Q2 \\
Phys.6 & 23 & $\mathrm{Q} 1$ & X2 (feedback) & Q2 \\
Phys.7 & 41 & $\mathrm{Q} 1$ & X3 (module) & Q2 \\
Phys.8 & 30 & $\mathrm{Q} 1$ & X3 (module) & Q2 \\
Phys.9 & 39 & $\mathrm{Q} 1$ & X3 (module) & Q2 \\
\hline
\end{tabular}

Explanation: Q1 = Pre-test, Q2 = Posttest, X1 = realistic video (Galileo's Famous. Gravity Experiment), X2 = narrative feedback, $\mathrm{X} 3=$ module of e-learning.

\subsection{Research Instrument and Data Collection}

The data were collected twice, namely before treatment (Q1) and after treatment (Q2) using a three-tier diagnostic test. These diagnostic tests were adopted from previous investigators $[8,61,62]$. The validity of the three-tier diagnostic test instrument-based elearning, which is measured by its validity and reliability values, has been tested and calculated by previous researchers as shown in Table 2 .

Table 2. Validity and reliability of three-tier diagnostic test-based e-learning.

\begin{tabular}{|c|c|c|c|c|c|c|c|c|c|}
\hline \multicolumn{9}{|c|}{ Validity Design and Media Expert } & \multirow[t]{2}{*}{ Reliability } \\
\hline & Content & perts & & De & and Med & xperts & & & \\
\hline $\begin{array}{c}\text { Content } \\
\text { Feasibility } \\
85 \%\end{array}$ & $\begin{array}{c}\text { Present. of } \\
\text { Questions } \\
86 \%\end{array}$ & $\begin{array}{l}\text { Lang. } \\
\text { Asses } \\
85 \%\end{array}$ & $\begin{array}{c}\text { Test } \\
\text { contents } \\
93 \%\end{array}$ & $\begin{array}{c}\text { Form. \& } \\
\text { display } \\
79 \%\end{array}$ & $\begin{array}{c}\text { Lay. } \\
\text { outline } \\
83 \%\end{array}$ & $\begin{array}{c}\text { Pack. \& eval. } \\
\text { Active. } \\
85 \%\end{array}$ & $\begin{array}{c}\text { Mean } \\
85.14 \%\end{array}$ & $\begin{array}{c}\text { Category } \\
\text { Very Decent }\end{array}$ & $\begin{array}{c}\text { Cronbach's } \\
\text { Alpha } \\
0.827\end{array}$ \\
\hline
\end{tabular}

Based on the results of the experts' assessment, as shown in Table 2, it can be seen that the three-tier diagnostic test had validity and reliability that were very feasible and reliable.

The purpose of the test instrument is to identify the level of the misconception of the students majoring in physics, chemistry, and biology education in basic physics courses, especially in the misconception of the free-fall motion concept. The test consisted of 8 items with three tiers: the first level is stimulus, the second level is the answer certainty index (CRI index) (1-5 indexes), and the third level consists of the reasons for the selected answers at the first level. The three-tier diagnostic test instrument grids are shown in Table 3.

\subsection{Treatments}

The research implementation began with face-to-face lectures conventionally in the basic physics course for all classes (Phys.1-Phys.9). At the 9th meeting, the students were directed to take midterm exams using an e-learning module. At the beginning of the test, all respondents were required to answer the three-tier diagnostic test in the form of a pretest (Q1), then followed by the treatment $(\mathrm{X})$ and the posttest $(\mathrm{Q} 2)$. Regarding the design arranged above (Table 1), the first treatment (X1) used realistic video in Phys. 
1-3 classes. The respondents were given $30 \mathrm{~min}$ to observe a realistic video about the difference in falling time between an iron ball and chicken feathers in a vacuum laboratory on the topic of free-fall motion. After that, it was followed by the posttest activities on the same topic. The next treatment employed narrative feedback (X2) in the Phys.4-6 classes. Narrative feedback was a physical explanation of each answer to each question that had been chosen by the respondents on the pretest, either the wrong answer or the right answer. Narrative feedback was given after the respondents completed the pretest for $30 \mathrm{~min}$ before completing the posttest. The respondents who had read the narrative feedback carefully would get information about the reasons for the wrong or correct answers they had chosen in the pretest.

Table 3. Instruments lattice of three-tier diagnostic test $[8,61,62]$.

\begin{tabular}{|c|c|c|c|c|c|}
\hline \multirow{2}{*}{ Topic } & \multirow{2}{*}{ Sub-Concept } & \multicolumn{4}{|c|}{ Three-Tier Diagnostic Test } \\
\hline & & One-Tier & Two-Tier & Three-Tier & Items \\
\hline \multirow{7}{*}{$\begin{array}{l}\text { Free-fall } \\
\text { motion }\end{array}$} & The concept of free-falling object weight & Stimulus (1a) & CRI (1b) & Reason (1c) & 1 \\
\hline & The concept of free-falling object size & Stimulus (2a) & CRI $(2 b)$ & Reason (2c) & 2 \\
\hline & The concept of free-falling object shape & Stimulus (3a) & CRI $(3 b)$ & Reason (3c) & 3 \\
\hline & The concept of free-falling object action-reaction & Stimulus (4a) & CRI (4b) & Reason (4c) & 4 \\
\hline & The concept of free-falling object acceleration & Stimulus $(5 a, 6 a)$ & CRI $(5 b, 6 b)$ & Reason $(5 c, 6 c)$ & 5,6 \\
\hline & The concept of free-falling object trajectory & Stimulus (7a) & CRI (7b) & Reason $(7 \mathrm{c})$ & 7 \\
\hline & The concept of free-falling object gravity force & Stimulus (8a) & CRI $(8 b)$ & Reason (8c) & 8 \\
\hline
\end{tabular}

The last treatment was the use of an e-learning module on the free-fall motion concept (X3) for the Phys.7-8 classes. The contents of this e-learning module were the basic theories of free-fall motion. The discussion of the e-learning module was not related to the answers from the pretest that had been chosen by the respondents but only to a general description of the free-fall motion concept. The respondents who had good reasoning could relate the contents of the e-learning module to the pretest answer choices. This means that for this type of research with a three-group pretest-posttest design, the respondents who had a high baseline would also have a high posttest score $[63,64]$

\subsection{Data Analysis}

The level of effectiveness of the media is based on the misconception reduction percentage as a result of the given treatment. The collected data were in the form of test scores on a scale of $0-100$. The data analysis was carried out in two stages. The first stage was the analysis of the misconception percentage (Mis), lack of knowledge (LK), lucky guess (LG), knowledge of correct concepts (KCC) using descriptive statistics, and reference to the decision matrix based on the CRI index $[65,66]$. The second stage was the data analysis to determine the reduction in misconception between the score before the treatment (pretest) and the score after the treatment (posttest). This second stage of the data analysis was carried out using the Normalized gain formula and the calculation method was adopted from the previous researchers [67-73]. The results of the data analysis were displayed in a graphical form and also in Table 3.

\section{Results}

In accordance with the objectives of the study as formulated in the introduction, the data displayed are related to (i) the contribution of the pretest results to the posttest, (ii) the impact of treatment on reducing misconception, and (iii) the level of effectiveness of the type of treatment in terms of the free fall motion sub-concept. The magnitude of the contribution of each of these factors was described in subtopics 3.1, 3.2 and 3.3.

\subsection{The Contribution of the Pretest to the Posttest Score}

This section highlights research data related to the impact of the pretest on posttest scores. The contribution of the pretest to posttest scores was differentiated according to 
each treatment class, namely the narrative feedback class, the e-learning module class, and the realistic video class.

\subsubsection{The Pretest of Narrative Feedback Class}

Narrative feedback was given to the respondents after completing the pretest and before following the posttest. The data on the impact of the pretest scores on the posttest scores in the treatment class using narrative feedback is shown in Figure 1.

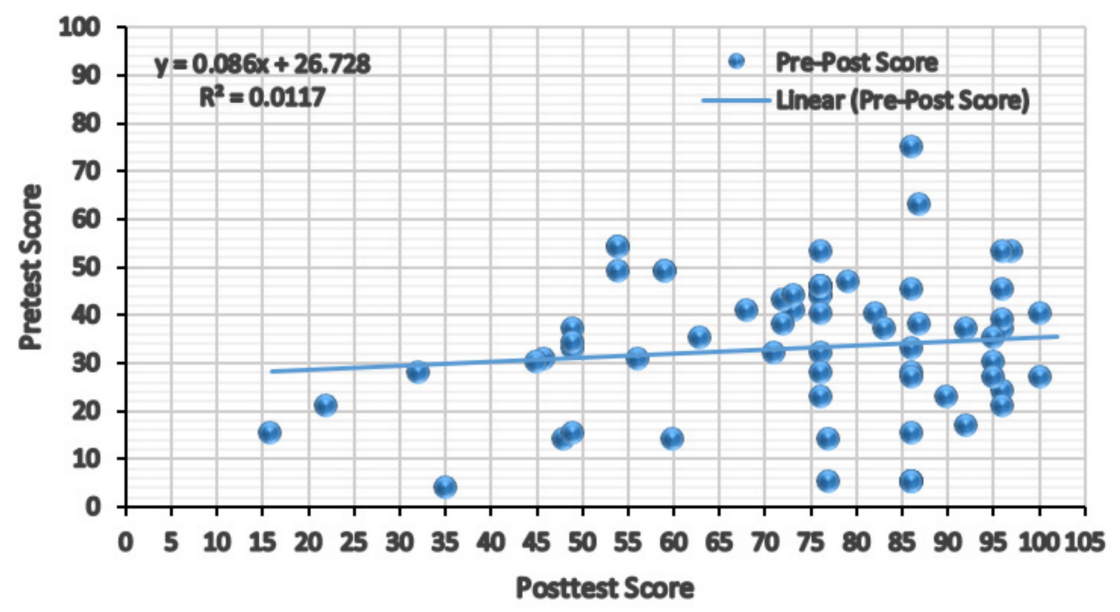

Figure 1. Contribution of pretest to posttest for narrative feedback treatment.

Table 4 shows some examples of the kind of narrative feedback used in the Phy.5-Phy.6 classes. Students' answers and the intervention with descriptive feedback are also shown in Table 4.

Table 4. Examples of students' answers and the content of narrative feedback used.

\section{Questions and Students' Answers}

Q1: Two metal balls (A and B) are the same size, but the weight of ball A is twice the weight of ball B. Both are dropped from a building with the same height. The time it takes for the two balls to reach the ground is:

A1: The time for ball B is about half that of ball A.

Q2: Two metal balls (C and D) weigh the same, but the size of ball C is 10 times the area of ball D. Both are dropped from a building with the same height. The time it takes for the two balls to reach the ground is:

A2: Time for ball $C$ is $1 / 10$ of the time that ball $D$ falls.

\section{Narrative Feedback}

F1: The answer is incorrect, because it is theoretically and practically impossible for light objects to fall faster than heavy objects

F2: The answer is incorrect, because ball $C$ falls faster, while the plane of ball $C$ is wider than ball $D$. In this problem, there is no information ignoring air friction, meaning that air friction is still taken into account. Thus it is impossible for ball $\mathrm{C}$ to fall faster than ball $\mathrm{D}$, while the cross-sectional area of ball $\mathrm{C}$ is wider than ball D, this is not according to everyday experience. Meanwhile, according to the theory, the size and weight of the object has no correlation with the time it fell.

$\mathrm{Q}=$ Question; $\mathrm{A}=$ Answers and $\mathrm{F}=$ Narrative Feedback .

\subsubsection{The Pretest of E-learning Module Class}

The data of the impact of the pretest on the posttest in the class using the e-learning module as treatment is shown in Figure 2.

\subsection{The Contribution of the Treatment to the Posttest Score}

Besides the initial ability of the respondents, which was indicated by the pretest results, the increase in the posttest score was also influenced by the treatment given between the pretest and posttest. The results of the narrative feedback treatment, E-learning modules and realistic video viewed from the point of increasing the score of posttest results were as follows. 


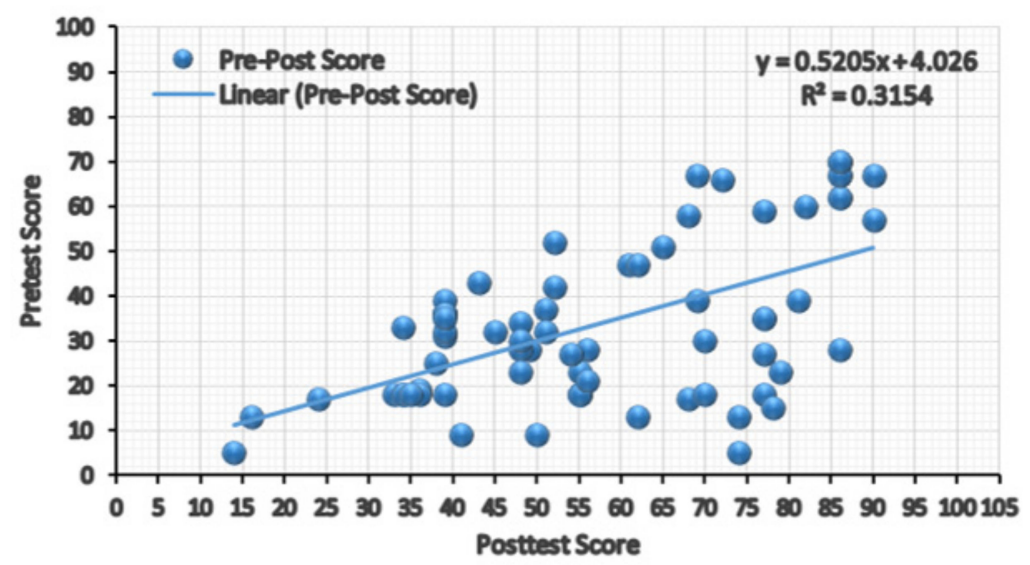

Figure 2. Contribution of pretest to posttest for e-learning module treatment.

\subsubsection{The Pretest of Realistic Video Class}

The data of the impact of the pretest on the posttest in the treatment class using realistic video in the free-fall motion concept is shown in Figure 3.

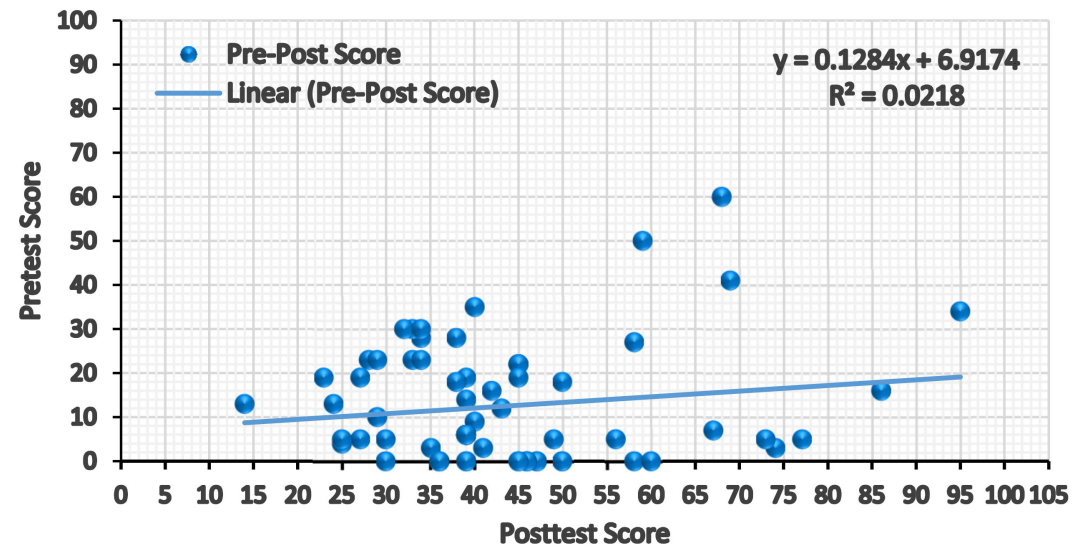

Figure 3. Contribution of pretest to posttest for realistic video treatment.

3.2.2. Treatment of Narrative Feedback

After reading all the narrative feedback for each item, the participants carried out the posttest activity and the results are shown in Figure 4.

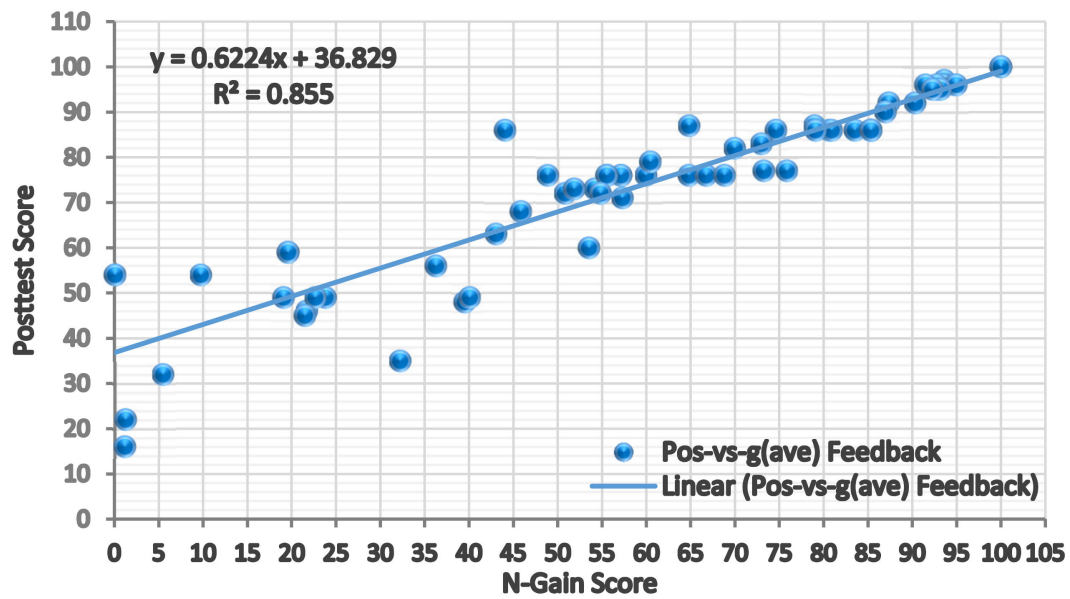

Figure 4. Impact of narrative feedback treatment to posttest score. 


\subsubsection{Treatment of E-Learning Module}

The result of the treatment of module which was inserted into the Moodle-based elearning media and activated (unhidden) after the participants answered all the questions in the pretest are shown in Figure 5.

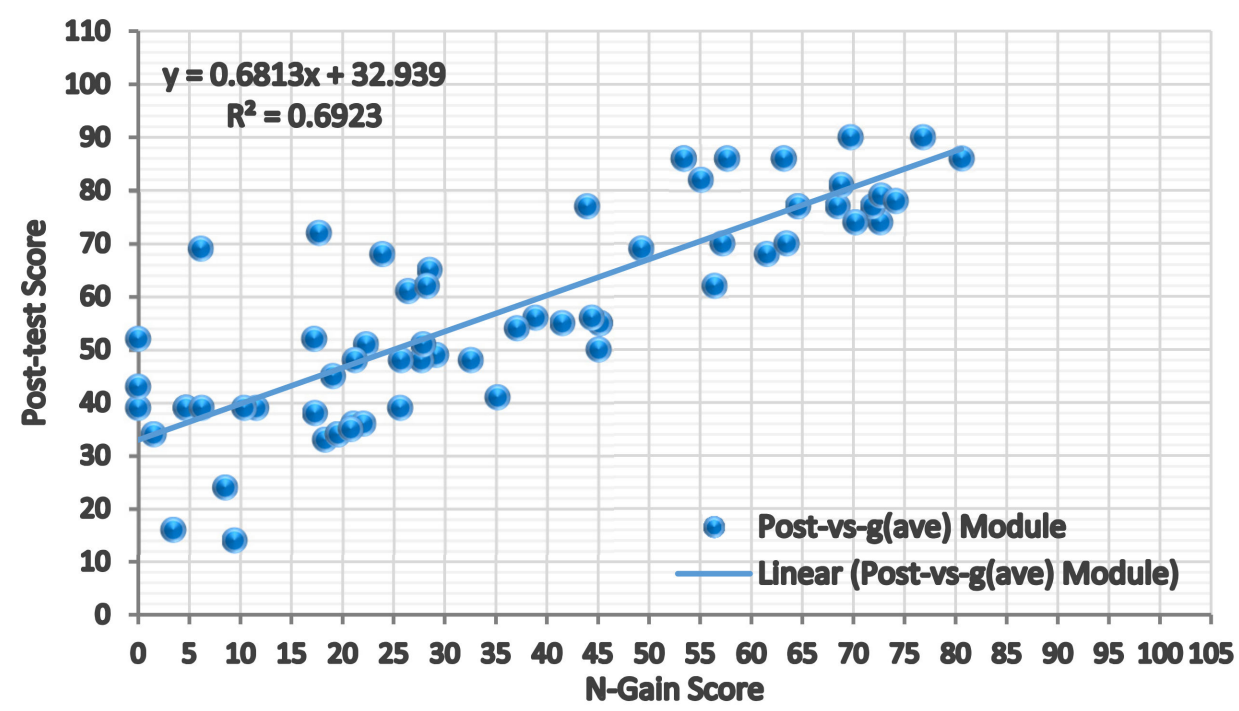

Figure 5. Impact of module treatment to posttest score.

\subsubsection{Treatment of Realistic Video}

The final treatment is watching a realistic video of free-fall motion. Just like the previous treatment, the participants worked on the pretest, watched the realistic video, and finally carried out the posttest activities. The results of the posttest activities are shown in Figure 6.

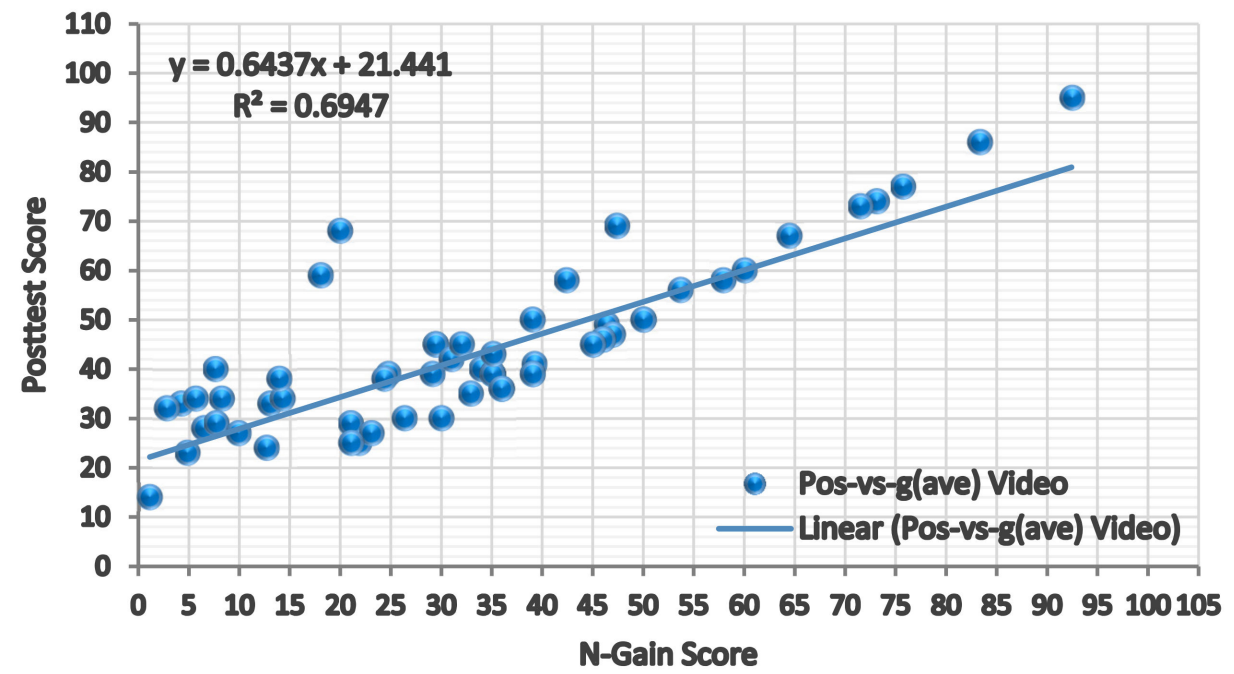

Figure 6. Impact of realistic video treatment to posttest score.

\subsection{The Result of the Items Analysis}

Based on the pretest, treatment, and posttest that have been completed by the participants, the impact of the treatment on each sub-concept of free-fall motion can be found. The results of item analysis for each sub-concept of the treatment are shown in Table 5. 
Table 5. Item analysis of three-tier diagnostic test $(\mathrm{N}=281)$.

\begin{tabular}{|c|c|c|c|c|c|c|c|c|c|c|}
\hline \multirow{2}{*}{ Items } & \multirow{2}{*}{ Sub-Concepts } & \multicolumn{3}{|c|}{ Feedback } & \multicolumn{3}{|c|}{ Module } & \multicolumn{3}{|c|}{ Video } \\
\hline & & Pre & Post & $<\mathrm{g}>$ & Pre & Post & $<\mathrm{g}>$ & Pre & Post & $<\mathrm{g}>$ \\
\hline 1 & Weight in free falling objects & 1.07 & 3.48 & 0.55 & 1.15 & 3.07 & 0.50 & 0.28 & 0.77 & 0.10 \\
\hline 2 & Size in free falling objects & 2.62 & 4.48 & 0.73 & 2.29 & 2.63 & 0.12 & 1.22 & 2.95 & 0.46 \\
\hline 3 & Shape in free falling objects & 1.85 & 4.16 & 0.74 & 2.58 & 3.48 & 0.37 & 1.36 & 2.93 & 0.43 \\
\hline 4 & Action-reaction force in free falling objects & 0.00 & 2.27 & 0.45 & 0.06 & 1.90 & 0.03 & 0.15 & 0.24 & 0.02 \\
\hline 5 & Falling acceleration in free falling objects & 2.92 & 4.42 & 0.65 & 2.80 & 3.75 & 0.43 & 0.70 & 3.76 & 0.71 \\
\hline 6 & A trajectory in free falling objects & 0.40 & 2.27 & 0.39 & 1.39 & 2.72 & 0.37 & 0.28 & 1.09 & 0.17 \\
\hline 7 & Force of gravity on free falling objects & 0.87 & 2.71 & 0.41 & 0.20 & 0.47 & 0.06 & 0.19 & 0.61 & 0.09 \\
\hline \multirow[t]{2}{*}{8} & Force of drag on falling objects & 2.85 & 3.66 & 0.42 & 3.32 & 3.50 & 0.11 & 0.74 & 3.69 & 0.69 \\
\hline & Average & 1.57 & 3.43 & 0.54 & 1.72 & 2.47 & 0.25 & 0.61 & 2.01 & 0.33 \\
\hline
\end{tabular}

\section{Discussion}

\subsection{The Contribution of the Pretest Score to the Posttest Scores (Q1)}

The results of the data analysis of the treatment with narrative feedback show that the pretest scores were correlated with the posttest scores with a correlation coefficient of about 0.11 , which belongs to the low positive correlation category. In other words, each individual's pretest results contributed to the posttest score of about $1.17 \%$ with a very low category. This means that there were participants, in certain sub-concepts, with a low baseline who could achieve a higher score in completing the posttest or vice versa. As an example of the data shown in Table 1, for the sub-concept of "pair of action-reaction forces in free fall" with an average baseline of 0.00 , the posttest score was about 2.27. In contrast, for the sub-concept of "weight factor in free fall objects" with a baseline of 2.85, the score of the posttest was 3.66. Based on these two data, it can be said that for a class with narrative feedback treatment, the pretest score did not contribute to the posttest results. This could be proven by the distribution graphs of the pretest and posttest in Figure 1, where the distribution of data was more concentrated in the areas of high posttest scores and corresponds to low pretest scores. This illustrated that the results of the students with low pretest were higher after following the posttest treatment, meaning that the treatment factor with narrative feedback was more dominant on posttest results.

This fact was also supported by the data on the relationship between the narrative feedback treatment and the posttest scores, as shown in Figure 4 . The level of narrative feedback treatment contribution to posttest scores was indicated by the high or low N-Gain value, as well as by the correlation coefficient between the two. The results of the data analysis showed that the correlation coefficient between the two was around 0.92, which belongs to a high positive category. It means that the increase in posttest score up to $85.5 \%$ was caused by the feedback of the treatment to the participants after completing the pretest on free fall motion through e-learning media. While the other was caused by the pretest score as shown in Figure 1. Several previous research results show that narrative feedback was one of the significant factors on learning and learning achievement [39]. Narrative feedback could improve learning outcomes from the initial stage to the next stage after being given narrative feedback [41], and the method of scoring automatically done as in online learning. The students preferred to revise their work after receiving narrative feedback even though they had higher initial scores [42].

The data in Figure 2 provide the information about the contribution of pretest scores to posttest scores for classes with the module treatment. The results of the data analysis showed that for the module class, the pretest and posttest score were relatively higher than the narrative feedback class and the realistic video class with a correlation coefficient of 0.56 , which is in a high positive correlation category. The results of the data analysis also showed that for the treatment class with modules, around $31.54 \%$ of the pretest scores contributed to the posttest scores. In other words, many students who had high pretest scores also had high scores posttest, as shown by the data distribution of pretest and 
posttest scores in Figure 2. The distribution of scores below the correlation line indicated that the students had low pretest scores but high posttest scores. The concept of gravity on free-falling objects, as shown in Table 4, was one with a low pretest score and a high posttest score. While the distribution of scores above the correlation line means that the students had high scores both on the pretest and posttest. The distribution of such data was in line with the concept of drag in free-fall motion, as shown in Table 4, where the students had high scores on the pretest and the posttest.

On the other hand, the contribution of the treatment factor with the module to the posttest score was around $69.23 \%$, as shown in Figure 5. This means that the increase in the posttest score from the pretest on the concept of free-fall motion was mostly due to the treatment using the e-learning module. In other words, there was a strong correlation between the increase in the N-Gain score and the posttest score. This was indicated by the correlation coefficient value of around 0.83 with the high and positive category. Even so, the effect of using the e-learning module on the increase in posttest scores was still lower than the increase in posttest scores which applied when using narrative feedback as a treatment. Several previous research results indicated that the use of e-learning modules could increase students' knowledge and efficacy [26], had the greatest benefit in the subgroup of paramedical students who actively worked in the ambulance [31], and was effective for engineering students to learn entrepreneurial knowledge and skills [33].

The data in Figure 3 show the relationship between the pretest and the posttest scores for the treatment using realistic video. The content of realistic video was a video of moving objects free-falling in a giant laboratory free of air. After the students worked on the pretest, they were given $25 \mathrm{~min}$ to observe the phenomena of free-fall through the realistic video, and then they were given the posttest. The result of the data analysis shows that the correlation coefficient between the pretest and posttest scores was 0.15 with the low positive category. It means the increase in posttest scores was less dominated by high or low pretest scores. This fact was shown by the distribution of pretest and posttest scores in Figure 3, where the scores spread below the correlation line with low pretest scores but high posttest scores. Other findings were shown in Table 1, in which there were two concepts with low pretest scores but high posttest scores, namely, the concept of inhibition and the acceleration of free-falling moving objects with N-Gain values of 0.69 and 0.71 .

Meanwhile, the contribution of the realistic video treatment to the posttest scores was presented in Figure 6. The relationship between the posttest scores and the increase in rates due to the treatment through observing the realistic video, which is shown by the correlation coefficient between the two, is about 0.83 , which is high and has a positive category. The contribution of the treatment using realistic videos to the posttest score was around $69.47 \%$. This means that the increase in posttest scores from the pretest on the concept of free-fall motion was mostly due to the treatment using realistic videos. Several past studies also showed that the use of video in the learning process was more beneficial for students who rarely took face-to-face lectures [46]. It was more meaningful if the video replaced face-to-face lectures [48] because it provided more general, fast, accessible, attractive, and reliable feedback [49]. Besides, it could improve students' critical thinking skills [51].

\subsection{The Impact of Treatments toward the Posttest Score (Q2)}

Based on the data in Figures 4-6 above, the most dominant treatment on the posttest scores was narrative feedback. The reason for this is that narrative feedback was more focused and also clearer for the students to answer in the pretest. The participants knew the status of the answer, whether it was true or false. Besides, they could also understand the reasons directly. The second most dominant narrative feedback influencing posttest scores was realistic video. This was because the content of the realistic video was related to a real experiment in the laboratory on the comparison of the falling time between chicken feathers and iron balls, where the size, shape, and weight of the two were very different. In other words, the students got the right answer after seeing a realistic video about free-fall motion. E-learning module feedback was in the last rank in terms of its contribution to 
the increase of posttest scores. One of the reasons was that the e-learning module used in this study was in the form of a narrative and contained general explanations of moving objects in free fall. Only the students who had good reasoning abilities could relate the module content to the answers that had been selected in the pretest. This means that only the students who had high pretest scores would have high scores in the posttest. This can be seen in the data in Table 5. The respondents who had high baselines on the concept of shape, acceleration, and drag of free-falling objects would also have high posttest results on the same concept.

\subsection{The Impact of Treatments to the Reduction of Misconception (Q3)}

Reducing the students' misconception related to the concept of free-fall motion was the main objective of this study. Some of the results of the previous studies show that the identification of conceptual understanding in science learning, especially physics, was categorized into (a) knowledge of correct concepts (KCC), (b) lucky guessing (LG), (c) lack of knowledge (LK), and (d) misconception (Mis) [8-11]. The results of the previous studies also show that every effort made to reduce misconception was only part of (a) knowledge of correct concepts and (d) misconception, which has more dominant changes $[61,62,65,66]$. The first stage analysis of this study also shows that the LG and LK categories were less dominant, experiencing a change in the percentage between before treatment (pretest) and after treatment (posttest). This means that before making efforts to reduce misconception, the percentage of the students who mastered the concept correctly was very small compared to the percentage of the students who experienced misconception. However, after remediation, the opposite occurred, where the percentage of the students who experienced misconception decreased and the percentage of the students who mastered the concept correctly (KCC) increased. Based on some evidence from the results of the previous studies and the results of the data analysis at the initial stage of this study, this study employed the posttest score benchmark as an indicator of reducing students' misconception on the concept of free-fall motion. In other words, students who had high posttest scores had understood the concept of free-fall motion correctly.

Misconception remediation in the form of narrative feedback, realistic videos, and e-learning modules that have been carried out in this study has had different impacts. Based on the results of the data analysis, it can be said that the treatment in the form of narrative feedback after completing the pretest was more effective in reducing the misconception percentage compared to the other two forms of treatment. It turns out that the narrative explanation related to the reasons per test item for wrong answers and also for correct answers was easier to understand by the students. They also discovered that they misunderstood how to do the task related to free-fall motion. Several previous research results have also proven that the use of narrative feedback on test answers was very effective in reducing misconception [74].

The second treatment which was also effective in reducing misconception was realistic videos treatment. Realistic video feedback provided a visual explanation of the concept that the students have misunderstood concerning the falling time when two objects have different shapes, sizes, and weights. The pre-concept encountered by the students in their daily environment was that when two objects with different weights fell, the falling time would be different. The realistic video shows that an iron ball and chicken feathers falling from the same height in a vacuum would have the same falling time. The students who watched this realistic video would get answers to the misconception in answering the pretest. It means the respondents who observed realistic videos would decrease the percentage of the misunderstanding of the free-fall motion concept. This fact was shown by the data presented in Table 1, where the increase in understanding was around 33\% from the pretest score. Several previous research results also stated that the use of video could reduce the percentage of misconception, including reducing misconception in the topic of static fluids [10], automobile braking distances [54], bullet motion [56-58], and science [74]. 
The content of the e-learning module was related to a general discussion of the basic theory of free-fall motion, including definitions, concepts, equations, and some examples of free-fall motion applications. The description of the e-learning module content was not directly related to the answer chosen by the respondents in the pretest, but if the respondents had good reasoning power, they would be able to relate the e-learning module content to the answers chosen in the pretest. This fact is shown by the data in Table 4.

\subsection{The Treatments vs. Subconcepts of Free-Fall Motion (Q4)}

The treatment employed in this study (narrative feedback, realistic video, and elearning module) had different characteristics and advantages. The advantage of narrative feedback was a description of the reasons for each answer chosen by the respondent. The advantage of realistic videos was that they could clearly show the difference in the falling time between the iron ball and the chicken feathers in the vacuum. Meanwhile, the advantage of the e-learning module was that there were several sources and activities related to the topic of free-fall motion. Based on the differences in the characteristics of each type of treatment, the percentage of reduction in misconception varied for different sub-concepts of free-fall motion (see Table 4). The findings of this statement were exposed by the data in Table 4, where the type of narrative feedback treatment was more effective in reducing the percentage of misconception in the sub-concept of size, shape, and acceleration of free-falling objects. While the type of realistic video treatment was effective in reducing the percentage of misconception in the acceleration and drag forces of free-falling objects. While the type of treatment of the e-learning module was effective in reducing the percentage of the weight and acceleration of free-fall motion objects. The data in Table 4 also showed that the misconception percentage reduction in the free-fall acceleration sub-concept was suitable for all treatment types.

\section{Conclusions}

There were several important findings in this study. First, the contribution of the initial baseline of the respondents to the final score (posttest) was very low in the class with narrative feedback treatment, and the highest one was in the class with e-learning modules treatment. Second, the best feedback treatments used to reduce the misconception percentage in the concept of free-fall motion were narrative feedback and realistic video. Third, efforts to reduce the misconception percentage in the size and shape of free-fall objects were best employed with narrative feedback. Fourth, in efforts to reduce the percentage of misconception in the acceleration of falling objects, the three types of treatments could be utilized. However, this research is limited to basic physics concepts, the respondents come from different fields of science, and the modules used are not directly related to the questions and answers in the pretest. Further study is expected to be able to select advanced physics concepts, respondents from the same field of science, and the content of the module related to the questions and answers in the pretest.

Author Contributions: Conceptualization, A.H. and L.H.; methodology, E.M., A.H.; software, I.I.; validation, L.H.; formal analysis, E.M.; investigation, I.I.; resources, A.H.; data curation, A.H.; writingoriginal draft preparation, A.H. and A.H.; writing-review and editing, A.H., L.H.; visualization, M.Y., E.M.; supervision, M.Y.; project administration, I.I. and E.M. All authors have read and agreed to the published version of the manuscript.

Funding: The directorate of research and community service directorate general of research and development strengthening the Ministry of Research, Technology and Higher Education Indonesia which has provided funds in accordance with the Research Contract for the 2020 Fiscal Year Number: 099/SP2H/LT/DPRM/2020 Date 8 May 2020.

Institutional Review Board Statement: The study was conducted according to the guidelines of the Ministry of Research, Technology and Higher Education Indonesia via Institute for Research and Community Services, Syiah Kuala University. 
Informed Consent Statement: Informed consent was obtained from all participants involved in the study.

Data Availability Statement: The data presented in this study are publicly available.

Conflicts of Interest: The authors declare no conflict of interest.

\section{References}

1. Styer, D.F. Common misconceptions regarding quantum mechanics. Am. J. Phys. 1996, 64, 31-34. [CrossRef]

2. Brown, D.E.; Clement, J. Overcoming misconceptions via analogical reasoning: Abstract transfer versus explanatory model construction. Instr. Sci. 1989, 18, 237-261. [CrossRef]

3. Fast, G.R. Using analogies to overcome student teachers' probability misconceptions. J. Math. Behav. 1997, 16, 325-344. [CrossRef]

4. Slotta, J.D.; Chi, M.T. How Physics Novices Can Overcome Robust Misconception through Ontology Training. Manuscript Submitted for Publication. 1999. Available online: http://www.public.asu.edu/ \{\}mtchi/papers/Slottaandchi.pdf (accessed on 24 March 2021).

5. Quijas, P.G.; Aguilar, L.A. Overcoming misconception in quantum mechanics with the time evolution operator. Eur. J. Phys. 2007, 28, 147-165. [CrossRef]

6. Marshall, H.A. Countering Astronomy Misconception in High School Students; University of Texas at Dallas: Richardson, TX, USA, 2003; pp. 1-14.

7. Podolner, A.S. Eradicating Physics Misconception Using the Conceptual Change Method. Ph.D. Thesis, Kalamazoo College, Kalamazoo, MI, USA, 2000.

8. Halim, A.; Meerah, T.S.; Halim, L. Pembinaan dan Penggunaan Ujian Diagnostik ke Arah Mengenal Pasti Salah Konsep Pelajar dalam Kursus Fizik kuantum. Sains Malays. 2009, 38, 543-551.

9. Halim, A.; Elmi Elisa Wahyuni, A.; Ngadimin Musdar Balqis, N.N. Development of concept maps diagnostic test for identification of students' misconception. AIP Conf. Proc. 2020, 2215, 05003.

10. Halim, A.; Mahzum, E.; Zanaton; Humairah, H. Impact of the EduPlasa interactive media on reducing misconceptions of static fluid in high school students. J. Phys. Conf. Ser. 2020, 1521, 022026. [CrossRef]

11. Halim, A.; Meerah, S.; Halim, L. Pengembangan dan Pengesahan Modul Pembelajaran Mandiri Berbasiskan Perubahan Konseptual Radikal. J. Pendidik. Pembelajaran 2011, 18, 127-132.

12. Brown, D.; Clement, J. Overcoming misconception via analogical reasoning: Factors influencing understanding in a teaching experiment. Instr. Sci. 1989, 18, 237-261. [CrossRef]

13. Stavy, R. Using analogy to overcome misconceptions about conservation of matter. J. Res. Sci. Teach. 1991, 28, 305-313. [CrossRef]

14. Tsai, C.-C. Overcoming Junior High School Students' Misconceptions about Microscopic Views of Phase Change: A Study of an Analogy Activity. J. Sci. Educ. Technol. 1999, 8, 83-91. [CrossRef]

15. Pekmez, E.S. Using analogies to prevent misconception about chemical equilibrium. Asia-Pac. Forum Sci. Learn. Teach. 2010, 11, 1-35.

16. Dilber, R. The effects of analogy on students' understanding of direct current circuits and attitudes towards physics lessons. Eur. J. Educ. Res. 2012, 1, 211-223. [CrossRef]

17. Maulana, P. Usaha Mengurangi Terjadinya Miskonsepsi Fisika Melalui Pembelajaran Dengan Pendekatan Konflik Kognitif. J. Pendidik. Fis. Indones. 2012, 6, 98-103.

18. Leinonen, R.; Asikainen, M.A.; Hirvonen, P.E. Overcoming students' misconceptions concerning thermal physics with the aid of hints and peer interaction during a lecture course. Phys. Rev. Spec. Top. Phys. Educ. Res. 2013, 9, 020112. [CrossRef]

19. Qian, Y.; Lehman, J.D. Using Targeted Feedback to Address Common Student Misconceptions in Introductory Programming: A Data-Driven Approach. SAGE Open 2019, 9, 1-20. [CrossRef]

20. Rodgers, C.R. Attending to Student Voice: The Impact of Descriptive Feedback on Learning and Teaching. Curric. Inq. 2006, 36, 209-237. [CrossRef]

21. Hattie, J.; Timperley, H. The power of feedback. Rev. Educ. Res. 2007, 77, 81-112. [CrossRef]

22. Hattie, J.; Biggs, A.J.; Purdie, N. Effects of learning skills intervention on student learning: A meta-analysis. Rev. Res. Educ. 1996, 66, 99-136. [CrossRef]

23. Owen, L. The Impact of Feedback as Formative Assessment on Student Performance. Int. J. Teach. Learn. High. Educ. 2016, 28, 168-175.

24. Zhu, M.; Lee, H.-S.; Wang, T.; Liu, O.L.; Belur, V.; Pallant, A. Investigating the impact of automated feedback on students' scientific argumentation. Int. J. Sci. Educ. 2017, 39, 1648-1668. [CrossRef]

25. Skipper, Y.; Douglas, K. The influence of teacher feedback on children's perceptions of student-teacher relationships. Br. J. Educ. Psychol. 2015, 85, 276-288. [CrossRef] [PubMed]

26. Flodén, J. The impact of student feedback on teaching in higher education. Assess. Eval. High. Educ. 2017, 42, 1054-1068. [CrossRef]

27. Cutumisu, M.; Schwartz, D.L. The impact of critical feedback choice on students' revision, performance, learning, and memory. Comput. Hum. Behav. 2018, 78, 351-367. [CrossRef]

28. Wieling, M.B.; Hofman, W.H.A. The impact of online video lecture recordings and automated feedback on student perfor-mance. Comput. Educ. 2010, 54, 992-998. [CrossRef] 
29. Borup, J.; West, R.E.; Thomas, R. The impact of text versus video communication on instructor feedback in blended courses. Educ. Technol. Res. Dev. 2015, 63, 161-184. [CrossRef]

30. Crook, A.; Mauchline, A.; Maw, S.; Lawson, C.; Drinkwater, R.; Lundqvist, K.; Orsmond, P.; Gomez, S.; Park, J. The use of video technology for providing feedback to students: Can it enhance the feedback experience for staff and students? Comput. Educ. 2012, 58, 386-396. [CrossRef]

31. Rodrigues, M.; Carvalho, P.S. Teaching optical phenomena with Tracker. Phys. Educ. 2014, 49, 671-677. [CrossRef]

32. Halim, A.; Safitri, R.; Nurfadilla, E. The development of multi representation practicum modules with PhET in Hooke's law concept. J. Phys. Conf. Ser. 2020, 1460, 012124.

33. Cidral, W.A.; Oliveira, T.; Di Felice, M.; Aparicio, M. E-learning success determinants: Brazilian empirical study. Comput. Educ. 2018, 122, 273-290. [CrossRef]

34. Halim, A.; Wahyuni, A.; Yani, E. The impact of the use of the internet on the learning outcomes in physics for high school student. J. Phys. Conf. Ser. 2020, 1521, 1-10. [CrossRef]

35. Al-Juda, M.Q.B. Distance Learning Students' Evaluation of E-learning System in University of Tabuk, Saudi Arabia. J. Educ. Learn. 2017, 6, 324-335. [CrossRef]

36. Shute, V.J.; Rahimi, S. Review of computer-based assessment for learning in elementary and secondary education. J. Comput. Assist. Learn. 2017, 33, 1-19. [CrossRef]

37. Ikram, U.Z.; Essink-Bot, M.-L.; Suurmond, J. How we developed an effective e-learning module for medical students on using professional interpreters. Med. Teach. 2015, 37, 422-427. [CrossRef] [PubMed]

38. Lahti, M.; Hätönen, H.; Välimäki, M. Impact of e-learning on nurses' and student nurses knowledge, skills, and satisfaction: A systematic review and meta-analysis. Int. J. Nurs. Stud. 2014, 51, 136-149. [CrossRef] [PubMed]

39. Ruiz, J.G.; Mintzer, M.J.; Leipzig, R.M. The Impact of E-Learning in Medical Education. Acad. Med. 2006, 81, 207-212. [CrossRef] [PubMed]

40. Shah, R.K.; Barkas, L.A. Analysing the impact of e-learning technology on students' engagement, attendance and per-formance. Res. Learn. Technol. 2018, 26, 1-18. [CrossRef]

41. El-Seoud, S.; Taj-Eddin, I.; Seddiek, N.; Ghenghesh, P.; El-Khouly, M. The impact of e-learning on Egyptian higher education and its effect on learner's motivation: A case study. Comput. Sci. Inf. Technol. 2014, 2, 179-187.

42. Suppan, L.; Stuby, L.; Gartner, B.; Larribau, R.; Iten, A.; Abbas, M.; Harbarth, S.; Suppan, M. Impact of an e-learning module on personal protective equipment knowledge in student paramedics: A randomized controlled trial. Antimicrob. Resist. Infect. Control. 2020, 9, 185. [CrossRef]

43. Visker, J.D.; Welker, K.; Rhodes, D.; Forsyth, E.; Melvin, P.; Cox, C. Effect of a rapid e-learning module and brief interprofessional simulation event on medical and nursing student collaborative attitudes and behaviors. Int. J. Nurs. Educ. Scholarsh. 2020, 17, 24-45. [CrossRef]

44. Erdil, N.O.; Harichandran, R.S.; Nocito-Gobel, J.; Li, C.Q.; Carnasciali, M. Impact of Integrated e-learning Modules in Developing an Entrepreneurial Mindset based on Deployment at 25 Institutions. In Proceedings of the 2017 ASEE Annual Conference \& Exposition, Columbus, OH, USA, 25-28 June 2017.

45. Diana, N.; Karyanto, P.; Sudarisman, S.; Indriyati, I. The Application of E-Module Based on Problem-Based Learning to Improve Critical Thinking Ability and Reduce Misconception on Ecology Material. Proc. Biol. Educ. Conf. Biol. Sci. Environ. Learn. 2016, 12, 242-247.

46. Imaningtya, C.D.; Karyanto, P.; Nurmiyati, N.; Asriayni, L. Penerapan e-module berbasis problem based learning untuk meningkatkan literasi sains dan mengurangi miskonsepsi pada materi ekologi siswa kelas. Bioedukasi J. Pendidik. Biol. 2016, 9, 4-10.

47. Halim, A. Improvement of High Order Thinking Skill of Physics Student to Prepare Human Resources In Order To Face of Global Competition in ASEAN Economic Community. J. Phys. Conf. Ser. 2018, 1116, 032009. [CrossRef]

48. Nuning, H.; Karyanto, P.; Fatmawati, U.; Mujiyati, M. The Application of E-Module Based on Problem-Based Learning to Im-prove Creative Thinking Ability and Reduce Misconception on Ecology. Proc. Biol. Educ. Conf. Biol. Sci. Environ. Learn. 2015, 12, $240-241$.

49. Kaniraras, D.A.; Karyanto, P.; Nurmiyati, N.; Kusumawati, L. The Application of E-module Using Problem Based Learning to Increase Higher Order Thinking Skill and Decrease Misconception in Ecosystem. Proc. Biol. Educ. Conf. Biol. Sci. Environ. Learn. 2015, 12, 186-192.

50. Wati, S.; Halim, A. The impact of the media tracker on student critical thinking skills. J. Phys. Conf. Ser. 2020, 1460, 012139. [CrossRef]

51. Wee, L.K.; Tan, K.K.; Leong, T.K.; Tan, C. Using Tracker to understand 'toss up' and free fall motion: A case study. Phys. Educ. 2015, 50, 436. [CrossRef]

52. Sulisworo, D.; Maruto, G. Tracker Application to Determine the Moment of Inertia in a Video-Based Laboratory to Improve Students' Learning Activity. In International Conference on Community Development; Atlantis Press: Dordrecht, The Netherlands, 2020; pp. 538-541.

53. Stadlbauer, J.M.; Kehrer, L.; Bauer, S. Using history to foster critical scientific thinking: Aristotle and Galileo's debate resolved through high-speed motion tracking in the classroom. Am. J. Phys. 2018, 86, 903-908. [CrossRef]

54. Hockicko, P.; Trpišová, B.; Ondrus, J. Correcting Students' Misconceptions about Automobile Braking Distances and Video Analysis Using Interactive Program Tracker. J. Sci. Educ. Technol. 2014, 23, 763-776. [CrossRef] 
55. Mufit, F.; Fauzan, A. The application of real experiments video analysis in the CCBL model to remediate the misconceptions about motion's concept. J. Phys. Conf. Ser. 2019, 1317, 012156. [CrossRef]

56. Wee, L.K.; Chew, C.; Goh, G.H.; Tan, S.; Lee, T.L. Using Tracker as a pedagogical tool for understanding projectile motion. Phys. Educ. 2012, 47, 448-455. [CrossRef]

57. Mufit, F. The Study of Misconception on Motion's Concept and Remediate Using Real Experiment Video Analysis. INA-Rxiv 2018. [CrossRef]

58. Kuhn, C.; Zlatkin-Troitschanskaia, O.; Brückner, S.; Saas, H. A new video-based tool to enhance teaching economics. Int. Rev. Econ. Educ. 2018, 27, 24-33. [CrossRef]

59. Hockicko, P.; Krišt'ák, L.U.; Němec, M. Development of students' conceptual thinking by means of video analysis and interactive simulations at technical universities. Eur. J. Eng. Educ. 2015, 40, 145-166. [CrossRef]

60. Subali, B.; Rusdiana, D.; Firman, H.; Kaniawati, I.; Ellianawati, E. Computer-Based Experiment of Free Fall Movement to Im-prove the Graphical Literacy. J. Pend. IPA Ind. 2017, 6, 23-46.

61. Halim, A.; Mustafa; Nurulwati; Soewarno; Nanda, N. Development of Two-Tier Diagnostic Test Based On E-Learning. J. Phys. Conf. Ser. 2018, 1120, 012030. [CrossRef]

62. Resta, N.N.; Halim, A.; Mustafa; Huda, I. Development of e-learning-based three-tier diagnostics test on the basic physics course. J. Phys. Conf. Ser. 2020, 1460, 012131. [CrossRef]

63. Bonate, P.L. Analysis of Pretest-Posttest Designs; CRC Press: New York, NY, USA, 2000.

64. Gliner, J.A.; Morgan, G.A.; Harmon, R.J. Pretest-Posttest Comparison Group Designs: Analysis and Interpretation. J. Am. Acad. Child Adolesc. Psychiatry 2003, 42, 500-503. [CrossRef] [PubMed]

65. Hasan, S.; Bagayoko, D.; Kelley, E.L. Misconceptions and the Certainty of Response Index (CRI). Phys. Educ. 1999, 34, 294-299. [CrossRef]

66. Hakim, A.; Liliasari; Kadarohman, A. Student Concept Understanding of Natural Products Chemistry in Primary and Sec-ondary Metabolites Using the Data Collecting Technique of Modified CRI. Int. Online J. Educ. Sci. 2012, 4, 544-553.

67. Bao, L. Theoretical comparisons of average normalized gain calculations. Am. J. Phys. 2006, 74, 917-922. [CrossRef]

68. Hake, R.R. Interactive-engagement versus traditional methods: A six-thousand-student survey of mechanics test data for in-troductory physics courses. Am. J. Phys. 1998, 66, 64-74. [CrossRef]

69. Laird, N. Further Comparative Analyses of Pretest-Posttest Research Designs. Am. Stat. 1983, 37, 329-330.

70. Dimitrov, D.M.; Rumrill, P.D., Jr. Pretest-posttest designs and measurement of change. Work 2003, 20, 159-165. [PubMed]

71. Von Korff, J.; Archibeque, B.; Gomez, K.A.; Heckendorf, T.; McKagan, S.B.; Sayre, E.C.; Schenk, E.W.; Shepherd, C.; Sorell, L. Secondary analysis of teaching methods in introductory physics: A 50 k-student study. Am. J. Phys. 2016, 84, 969-974. [CrossRef]

72. Coletta, V.P.; Phillips, J.A. Interpreting FCI scores: Normalized gain, reinstruction scores, and scientific reasoning ability. Am. J. Phys. 2005, 73, 1172-1182. [CrossRef]

73. Miller, K.; Lasry, N.; Reshef, O.; Dowd, J.; Araujo, I.; Mazur, E. Losing it: The Influence of Losses on Individuals' Normalized Gains. AIP Conf. Proc. 2010, 1289, 229-232.

74. Finney, M.J. The Role of Print and Video in Changing Science Misconception. Electron. J. Lit. Sci. 2002, 1, 1-25. 